\title{
Re-examination of kirwanite: a ferri-ferro- hornblende from Co. Down, Northern Ireland
}

\author{
RAB NAWAZ \\ Department of Geology, Ulster Museum, Belfast BT9 5AB \\ AND \\ GEORGE RYBACK \\ 42 Bell Road, Sittingbourne, Kent ME10 4EB
}

\begin{abstract}
$\mathrm{X}$-ray powder, optical, infrared, and chemical data suggest that kirwanite is an amphibole of composition $(\mathrm{Na}, \mathrm{K})_{0.10} \mathrm{Ca}_{1.80}\left(\mathrm{Fe}^{2+}, \mathrm{Mn}\right)_{3.10} \mathrm{Mg}_{0.79} \mathrm{Fe}_{1.14}^{3+} \mathrm{Al}_{0.78} \mathrm{Si}_{7.18} \mathrm{O}_{22}(\mathrm{OH})_{2}$ and thus corresponds to ferriferro-hornblende (Leake, 1978). The type locality, originally given as the NE coast of Ireland, is most likely Dunmore Head, Co. Down. Kirwanite occurs in the groundmass and the vesicles of variolitic andesite dykes of the Mourne dyke swarm. Thomson's original analysis of kirwanite was probably made on a mixture and the name should not be used for an amphibole species.
\end{abstract}

KIRWANITE was first named by $T$. Thomson (Bryce, 1831; Thomson, 1836)) after Richard Kirwan (1733-1812), the Irish chemist and natural philosopher, on the basis of an analysis by R. D. Thomson of specimens provided by Patrick Doran, the Irish mineral collector and dealer. Kirwanite is described (Thomson, 1836) as opaque, dark olive green in colour, with fibrous texture, the fibres divergent, forming brushes and filling cavities 'in a kind of basaltic rock'; hardness 2 , S.G. 2.941, analysis $\mathrm{SiO}_{2} 40.50, \mathrm{Al}_{2} \mathrm{O}_{3} 11.41, \mathrm{FeO}$ 23.91, $\mathrm{CaO} 19.78, \mathrm{H}_{2} \mathrm{O} 4.35$, total $99.95 \%$. Lacroix (1885) re-examined kirwanite optically and suggested that it was an altered amphibole mixed with epidote and quartz and his conclusion has been generally accepted (Hey, 1962; Leake, 1978).

There is some confusion about the type locality, given only as 'the $\mathrm{N}-\mathrm{E}$ coast of Ireland' by Thomson (1836) and as 'the Greenstone and Porphyry of Mourne' by Bryce (1833), but the evidence points to Dunmore Head, on the coast $7 \mathrm{~km}$ south of Newcastle, Co. Down. It is listed as 'peculiar to Down' by Bryce (1831). Patrickson (1837) noted the occurrence of kirwanite in dykes on the shore between Newcastle and Warrenpoint. Greg and Letsom (1858) list kirwanite from Glasdrumman, Kilkeel and Dunmore Head in Co. Down. Although Kilkeel is a town $13 \mathrm{~km} \mathrm{SSW,}$ and Glasdrumman a village $2.5 \mathrm{~km}$ south, of Dun-

Mineralogical Magazine, April 1989, Vol. 53, pp. 253-5 (C) Copyright the Mineralogical Society more Head, these names could easily have referred to one locality and, indeed, Hall (1868) lists Glasdrumman under Kilkeel when citing Greg and Lettsom's localities. Hall gives Dunmore Head, Co. Donegal, as an additional but almost certainly incorrect locality. Kirwanite is also supposed to have occurred in Co. Antrim (Greg and Lettsom, 1858; Hall, 1868), and there is a specimen so labelled in the Geological Museum, but this is probably a simple misinterpretation of 'the N-E coast of Ireland'.

The British Museum (Natural History) mineral collection contains specimens from Dunmore Head, Co. Down, and from Green Harbour $(0.5 \mathrm{~km}$ to the north), which presumably is the same locality as that of the three old specimens in the Ulster Museum, BELUM I1342, I2648 and I2649, all from Dunmore Head, Co. Down. The first one (I1342) matches the original description of Thomson (1836) and bears a Patrick Doran label and hence it was used in this study in preference to others. It differs from the other two Ulster Museum specimens and an identical third specimen from 'the N.E. coast of Ireland' in the Maidstone Museum (MM 75) in having the entire specimen surface, about $12 \mathrm{~cm}$ across, crusted by kirwanite, without the pale green corona or rim which surrounds the dark green kirwanite-filled cavities, $1-3 \mathrm{~cm}$ across, in the rest of the speci- 
Table 1. Electron microprobe analysis of kirwanite

\begin{tabular}{|c|c|c|c|c|c|}
\hline & $1 *$ & $2^{\$}$ & & & \\
\hline $\mathrm{SiO}_{2}$ & 45.94 & 45.94 & \multirow{2}{*}{\multicolumn{3}{|c|}{ Cations based on 23 oxyeens }} \\
\hline $\mathrm{Al}_{2} \mathrm{O}_{3}$ & 4.22 & 4.22 & & & \\
\hline $\mathrm{Cr}_{2} \mathrm{O}_{3}$ & 0.03 & 0.03 & $\mathrm{Si}$ & $7.18)$ & \multirow{3}{*}{8.00} \\
\hline $\mathrm{Fe}_{2} \mathrm{O}_{3}$ & N. Dtm. & 9.70 & $\mathrm{Al}$ & 0.78 & \\
\hline $\mathrm{FeO}$ & 31.32 & 22.59 & $\mathrm{Fe}^{3+}$ & $0.04)$ & \\
\hline $\mathrm{TiO}_{2}$ & 0.08 & 0.08 & $\mathrm{Fe}^{3+}$ & 1.10 & \multirow{5}{*}{5.00} \\
\hline Mno & 1.07 & 1.07 & $\mathrm{Ti}$ & 0.01 & \\
\hline Mgo & 3.40 & 3.40 & Mn & $0.15\}$ & \\
\hline NiO & 0.03 & 0.03 & $M g$ & $0.79^{\prime}$ & \\
\hline $\mathrm{CaO}$ & 10.75 & 10.75 & $\mathrm{Fe}^{2+}$ & 2.95 & \\
\hline $\mathrm{Na}_{2} \mathrm{O}$ & 0.44 & 0.44 & $\mathrm{Ca}$ & $1.80)$ & \multirow[t]{3}{*}{1.87} \\
\hline $\mathrm{K}_{2} \mathrm{O}$ & 0.31 & 0.31 & $\mathrm{Na}$ & $0.07\}$ & \\
\hline $\mathrm{H}_{2} \mathrm{O}$ & n.d & [1.92] & K & 0.03 & \\
\hline
\end{tabular}

* Specimen No. Belum I1342. Mean of 4 closely agreeing point analyses.

Total iron as $\mathrm{FeO} ; \mathrm{P}_{2} \mathrm{O}_{5}=0.01 \%$ neglected.

$\$ \mathrm{FeO}$ and $\mathrm{Fe}_{2} \mathrm{O}_{3}$ calculated by Droop's (1987) method;

$\mathrm{H} O$ from assumed $(\mathrm{OH})_{2}$.

mens. A fourth similar specimen (BELUM I10439) was collected in 1986 by one of the authors (R.N.) from a vesicular variolite of the composite dyke No. 55 (NGR: J 387244) of Tomkeieff and Marshall (1935), at Dunmore Head. They suggested that the kirwanite of Thomson (1836) could have come from this dyke, as a specimen collected from this dyke was identical to an old specimen in the mineral collection of the Geological Department of Armstrong College, Newcastleupon-Tyne, labelled 'Kirwanite (Thomson) N.E. Ireland'. The first specimen (BELUM I1342) was used for optical examination and to obtain an Xray powder pattern, an infrared spectrum, and an electron microprobe analysis (Table 1), all of which confirmed the identification as a clinoamphibole.

The microprobe analysis performed at Modena by Dr G. Vezzalini under the guidance of Prof. G. Gottardi (Table 1) shows it to be an iron-rich amphibole which, according to current nomenclature (Leake 1978), is a ferri-ferro-hornblende:

$$
\begin{array}{r}
(\mathrm{Na}, \mathrm{K})_{0.10} \mathrm{Ca}_{1.80}\left(\mathrm{Fe}^{2+}, \mathrm{Mn}\right)_{3.10} \mathrm{Mg}_{0.79} \mathrm{Fe}_{1.14}^{3+} \mathrm{Al}_{0.78} \\
\mathrm{Si}_{7.18} \mathrm{O}_{22}(\mathrm{OH})_{2} .
\end{array}
$$

The probe analysis is very different from that of Thomson (1836).

The green hornblende occurs both in the groundmass and in vesicles of variolite, a rock type of intermediate to basic composition but in most cases andesitic, which is an important mem- ber of the Mourne dyke swarm. Dyke No. 55 of Tomkeieff and Marshall (1935), the presumed type locality for kirwanite, is a composite dyke of olivine dolerite, three types of variolite (microvesicular, macrovesicular and xenoporphyritic) and olivine tholeiite. The macrovesicular variolite contains vesicles elongated and oriented parallel to the dyke walls, with a leucocratic zone or corona composed of alkali feldspar and quartz, surrounding a central fascicular aggregate of a green hornblende (kirwanite), occasionally with quartz. A large number of andesitic variolitic dykes, called 'Dunmore type' from their occurrence near Dunmore Head, and other similar ones further south, occasionally contain quartz, chlorite, calcite and epidote, in addition to kirwanite (Cole, 1892, 1894).

Thomson's analysis of kirwanite does not fit an amphibole formula and was probably made on impure material, perhaps containing epidote and calcite. Although our data show that Thomson did, indeed, discover an amphibole of unusual composition, the name he gave it should now be abandoned.

\section{Acknowledgements}

We are grateful to Dr G. Vezzalini and the late Prof. G. Gottardi for the microprobe analysis, to Miss Carol Lee Martin for an excellent English translation of Lacroix's French paper, and to Mr Eric Philp for the loan of the Maidstone Museum specimen.

\section{References}

Bryce, J. (1831) Tables of Simple Minerals, Rocks, and Shells. Simms and McIntyre, Belfast.

Bryce, J. (1833) List of the Simple Minerals of the Counties of Down, Antrim, and Derry. Phil. Mag. ser. 33, 83-7.

Cole, G. A. J. (1892) The variolite of Annalong, Co. Down. Sci. Proc. Roy. Dublin Soc. New ser. 7, 511.

Cole, G. A. J. (1894) On variolite and other tachylites at Dunmore Head, Co. Down. Geol. Mag. 31, 220.

Droop, G. T. R. (1987) A general equation for estimating $\mathrm{Fe}^{3+}$ concentrations in ferromagnesian silicates and oxides from microprobe analyses, using stoichiometric criteria. Mineral. Mag. 51, 451-5.

Greg, R. P. and Lettsom, W. G. (1858) Manual of the Mineralogy of Great Britain and Ireland. John van Voorst, London.

Hall, T. M. (1868) The Mineralogist's Directory. Edward Stanford, London.

Hey, M. H. (1962) An index of Mineral Species and Varieties. British Museum (Natural History), London.

Lacroix, M. A. (1885) Sur la kirwanite et al hullite. Bull. Soc. Mineral. France 8, 428-33. 
Leake, B. E. (1978) Nomenclature of amphiboles. Thomson, T. (1836) Outlines of Mineralogy, Geology, Mineral. Mag. 42, 533-63.

Patrickson, S. (1837) A descriptive list of the dykes and Mineral Analysis 1, 378.

appearing on the shore which skirts the Mourne Mountains, and numbered from Thomas's Mountain near Warrenpoint. J. Geol. Soc. Dublin 1, pt. 3 $182-5$.

Tomkeieff, S. I. and Marshall, C. E. (1935) The Mourne dyke swarm. Quart.J. Geol. Soc. 91, 251-92.

[Manuscript received 14 April 1988; revised 26 July 1988] 